\title{
Upper Extremity Surgery in Spastic Cerebral Palsy
}

\author{
Serebral Paralizide Üst Ekstremite Cerrahisi
}

\author{
Türker Özkan', Serdar Tunçer² \\ ${ }^{1}$ Department of Hand Surgery, Faculty of Medicine, Istanbul University, İstanbul, Turkey \\ ${ }^{2}$ Department of Plastic and Reconstructive Surgery, Faculty of Medicine, Istanbul Bilim University, İstanbul, Turkey
}

\begin{abstract}
Involvement of the upper extremity in cerebral palsy often results in a typical pattern of spasticity, with elbow flexion, forearm pronation, ulnar deviation and flexion of the wrist, and adduction-flexion posture of the thumb. Although only a relatively small subset of cerebral palsy patients are candidates for surgery, properly selected patients and procedures yield a reasonable improvement. Nonsurgical treatment modalities include physical therapy, orthoses, and medications aimed at decreasing spasticity. Surgical options for the management of the spastic upper extremity vary with the specific parts, however they are focused around three basic principles: weakening the overactive muscle/tendons, strengthening the underactive muscle/tendons, and stabilizing non-stable joints. Surgical management of the spastic upper limb in cerebral palsy requires meticulous evaluation and planning. It is important to know that upper extremity deformities are secondary manifestations of the cerebral injury. Therefore, in addition to evaluation of upper extremity function, consideration should be given to the intelligence and motivation of the patient, and voluntary use of the upper extremity. Prior to surgery, the overall level of function needs to be considered. These are also important details for the patients and their families, who should know that surgery is aimed at improving the upper extremity deformity, and not the primary disorder. Appropriately indicated surgery can significantly contribute to upper extremity function. (JAREM 2012; 2: 43-54)
\end{abstract}

Key Words: Cerebral palsy, spasticity, upper extremity surgery, tendon transfers

\section{ÖZET}

Serebral paralizide üst ekstremite tutulumu, tipik bir spastisite paterni oluşturur. Bunun sonucunda da sıklıkla dirsek fleksiyonu, önkol pronasyonu, el bileğinde fleksiyon ve ulnar deviasyon, başparmakta adduksiyon-fleksiyon postürüyle karakterize bir deformite meydana gelir. Serebral paralizi hastalarının yalnızca az bir kısmı cerrahi için uygun adaylar olsa da, uygun seçilmiş hastalarda cerrahi tedavi yüz güldürücü sonuçlar verebilmektedir. Cerrahi dışı tedaviler arasında fizik tedavi, ortezler ve spastisiteyi azaltmaya yönelik ilaçlar vardır. Spastik üst ekstremite tedavisindeki cerrahi seçenekler deformitenin bulunduğu bölgeye göre değişir, ancak üç temel özellik üzerinde odaklanır: aşırı aktif kas ve tendonların zayıflatılması, yetersiz aktiviteye sahip olan kas ve tendonların güçlendirilmesi ve stabil olmayan eklemlerin stabilizasyonu. Dirsek fleksiyon deformitesi serebral paralizide nadiren bir cerrahi endikasyon oluşturur, ancak ileri derecede olup işlevi engellediğinde biceps ve brachialis gevşetilmesi, fleksor pronator kas kaydırma gibi işlemler ile düzeltilebilir. Önkol pronasyon postürü, supinasyon gerektiren, ele alınan bir cismin avuç içinde tutulması veya kişisel hijyen gibi görevlerin yapılamamasına neden olabilir. Bu durumlarda ideal olan, mevcut pronasyonu bozmadan hastaya supinasyon hareketi kazandırmaktır. Fleksor karpi ulnarisin ekstansor karpi radialis brevis'e transferi, pronator teres rerouting, brachioradialis rerouting, brachialis rerouting işlemleri pronasyon deformitesinin tedavisinde kullanılabilecek işlemlerdir. El bileği fleksiyon deformitesi, ekstrensek parmak fleksorlarının tutma gücünü azaltır, bu nedenle tendon transferleri ile tedavi edilebilirler. Ancak, el bileğini ekstansiyona getiren her tedavinin, parmak ekstansiyonunu azaltabileceği akılda tutulmalıdır. El bilek ekstansiyonu için en sık yapılan işlem, fleksor karpi ulnarisin ekstansor karpi radialis brevis'e transferidir. Çok ileri olgularda el bilek artrodezi yapılabilir. Parmak fleksorleri gergin ise, fraksiyone uzatma, z uzatma veya yüzeyel fleksorların derin fleksorlara verildiği superficialis to profundus işlemi uygulanabilir. Başparmak serebral paralizili hastalarda avuç içinde kalmış olabilir. Bu durumda gevşetme ve tendon transferleri ile başparmağın abduksiyonu ve avuç içinden uzaklaştırıması amaçlanır. Serebral paralizide spastik üst ekstremitenin cerrahi tedavisi titiz bir değerlendirme ve planlama gerektirir. Üst ekstremite deformitelerinin serebral hasarın sekonder birer belirtisinin olduğu bilinmelidir. Bu nedenle, üst ekstremite işlevlerine ek olarak hastanın zeka düzeyi ve motivasyonuna, üst ekstremitenin istemli kullanımına dikkat edilmelidir. Ameliyattan önce üst ekstremitenin genel olarak kullanımına bakılmalıdır. Bunlar, ameliyatın hastalığın kendisini değil deformitelerini düzeltme amacını taşıdığını bilmesi gereken hasta ve aileleri için de önemli detaylardır. Uygun bir endikasyon ile yapılmış olan cerrahi tedavi, üst ekstremite işlevine anlamlı katkıda bulunacaktır. (JAREM 2012; 2: 43-54)

Anahtar Sözcükler: Serebral paralizi, spastisite, üst ekstremite cerrahisi, tendon transferleri

\section{INTRODUCTION}

Spasticity of the upper limb is most frequently caused by cerebral palsy, which describes a group of movement disorders attributed to nonprogressive injuries in the developing fetal or infant brain (1). Involvement of the upper extremity in cerebral palsy often results in a typical pattern of spasticity, with elbow flexion, forearm pronation, ulnar deviation and flexion of the wrist, and adductionflexion posture of the thumb (2). Cerebral palsy can be classified into spastic, dyskinetic, ataxic, or mixed types. The spastic type is often the type most suitable for surgical treatment, as the results are more predictable in the spastic group compared with others. The goal of surgery in a cerebral palsy patient should not be attaining a normal upper extremity, but rather to improve assistive function, posture, and hygiene. Surgical procedures are selected to improve activities of daily living, to increase the speed of hand flexion and extension, and improvement in the rotational axis of the forearm. Although only a small subset of cerebral palsy patients are candidates for surgery, properly selected patients and procedures yield reasonable improvements. Nonsurgical treatment modalities include physical therapy, orthoses, and medications aimed at decreasing spasticity.

Surgical options for the management of the spastic upper extremity vary with the specific parts, however, they are focused around three basic principles: weakening the overactive muscle/ tendons, strengthening the underactive muscle/tendons, and stabilizing non-stable joints. Weakening spastic muscles is the 
most predictable operative procedure. The muscle tendon unit is weakened by releasing its origin, detaching at the insertion, or lengthening the unit in the midportion, using $Z$ lengthening or fractional lengthening (3). Releasing the tendon at the origin or lengthening at midportion are preferable since they preserve some function, whereas release from the insertion often eliminates function of the muscle. Strengthening the weak muscles is often performed using tendon transfers. Due to the involvement of the central nervous system, re-education after transfer in the cerebral palsy patient is difficult. It is therefore preferable to use a donor tendon that is working "in-phase" with the desired function, which enables active function after surgery without comprehensive reeducation (3). Due to the difficulties in application and the unpredictability of the results, surgery and especially dynamic tendon transfers, are not recommended for the dyskinetic cases. Finally, stabilization of the joints is done either by plication of the joint capsule, or joint arthrodeses.

\section{Patient Evaluation}

The examination of the patient should be carried out in a calm setting with familiar people (4). Serial examinations are preferred, as the spasticity may affect upper extremity movement. The most important observation in the evaluation of the patient is whether the child voluntarily attempts to use the hand during activities. If the child does not use the hand, surgery is not advised. Surgery cannot induce functional activity in a functionally ignored limb, and will be of little benefit to the child (3).

The examination includes documentation of passive and active ranges of motion for the shoulder, elbow, forearm, wrist and fingers; muscle strength of upper limb motors; patterns of deformity; sensibility; functional activities of pinch, grasp, and release; and size measurements of circumference and length of arm, forearm and hand (4).

The passive range of motion of each joint is assessed. Long standing muscle spasticity with joint imbalance can lead to joint contractures, most often seen as elbow flexion or wrist flexion contractures (4). Measurement of Volkmann's angle is performed by extending the wrist while keeping the fingers extended. If extrinsic finger flexor contracture is present, it results in a wrist position less than neutral. Surgical correction of a wrist to neutral or dorsiflexed position in such a condition will cause a clenched fist unless the extrinsic finger flexors are corrected simultaneously. Next, the patient is observed while performing certain tasks. This will enable assessment of joint position, and the muscles responsible for the dynamic deformity. The authors use the House Functional Use Classification for overall assessment of upper limb function (Table 1).

\section{Timing of surgical treatment}

Although opinions on the subject are controversial, it is often reported that ideally the reconstructive surgery should be performed between the ages of 4-6. In this age range the central nervous system is mature and the deformities are easily detected. Also, the child can cooperate with the rehabilitation team (5-9). Even though surgery is recommended at early ages, a relatively older age is not a contraindication as long as the patient tries to control the hand voluntarily and the hand functionality is improved through its restoration (10).

In time, contractures develop in the motionless joints, while the skin and the soft tissues lose elasticity. Therefore, tendon transfers must be made as early as possible. In the meantime, the joint range of motion and elasticity of the soft tissues must be protected via passive exercises until surgery. It should be noted that no tendon transfer can activate a joint lacking passive movement and that the active movement of a joint cannot surpass its pretransfer passive movement. If it is impossible to overcome the spasticity, joint movement limitations and soft tissue contractures via intense and continuous rehabilitation treatments, then these problems must be solved by surgical release and lengthening techniques prior to tendon transfer.

\section{Surgical procedures according to the affected the upper extremity parts \\ Elbow}

Spastic elbow flexion deformity is usually present in hemiplegic children. The elbow enables the upper extremity to be spatially directed towards the target. Severe elbow flexion contractures may hold the arm attached to the body. In addition to problems with hygiene and cosmesis, the functionality is impaired (11). It is secondary to spasticity of the brachioradialis, biceps, and brachialis muscles. Although elbow flexion deformity is rather common, it is rarely severe enough to create a surgical indication. Generally, less than $30^{\circ}$ of flexion contracture in the elbow does not cause a functional limitation (12). Fixed contractures of $45^{\circ}$ or above or flexion deformities exceeding $80^{\circ}$ during activity are considered as surgical indications $(6,7)$. Among the most frequently used surgical techniques are loosening/lengthening

\section{Table 1. Upper extremity functional USG classification}

\begin{tabular}{|l|l|l|}
\hline Level & Designation & Activity level \\
\hline 0 & Does not use & Does not use \\
\hline 1 & Poor passive assist & Uses as stabilizing weight only \\
\hline 2 & Fair passive assist & Can hold onto object placed in hand \\
\hline 3 & Good passive assist & Can hold onto object and stabilize it for use by other hand \\
\hline 4 & Poor active assist & Can actively grasp object and hold it weakly \\
\hline 5 & Fair active assist & Can actively grasp object and stabilize it well \\
\hline 6 & Good active assist & Can actively grasp object and manipulate it against other hand \\
\hline 7 & Spontaneous use, partial & Can perform bimanual activities easily and occasionally uses the hand spontaneously \\
\hline 8 & Spontaneous use, complete & Uses hand completely independently without reference to the other hand \\
\hline
\end{tabular}



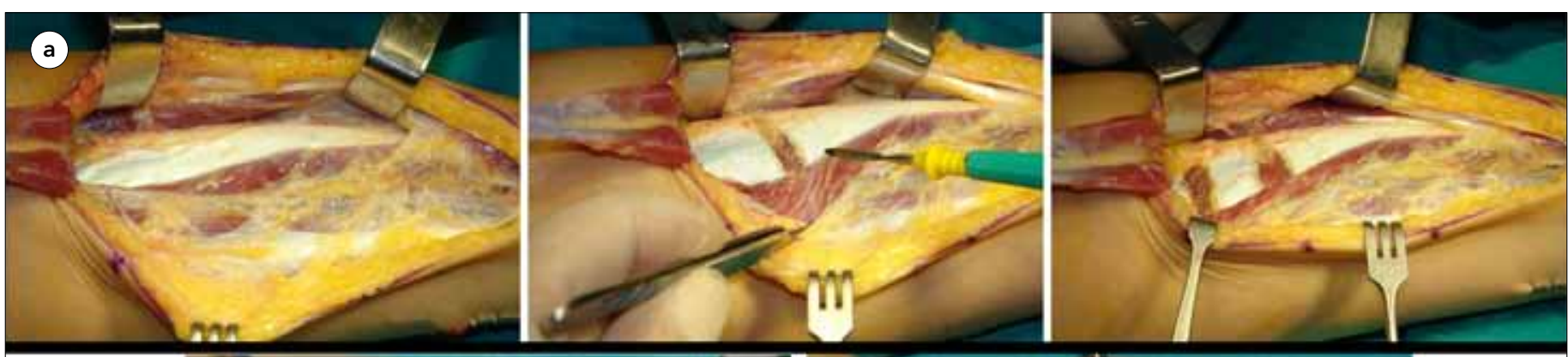

(b)
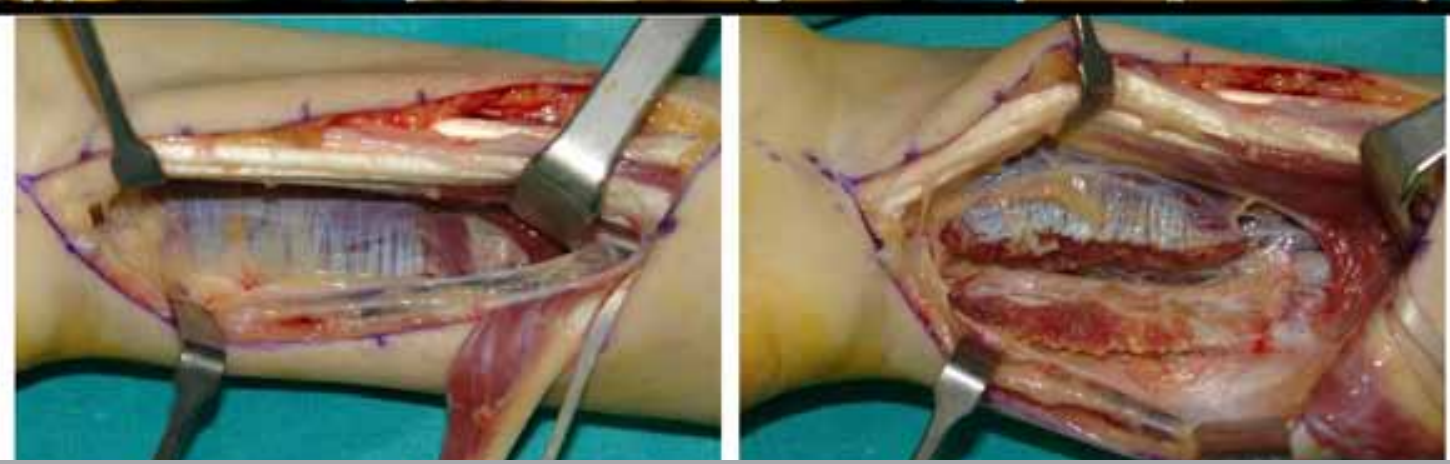

Figure 1. a) Pronator teres myotomy-lengthening, b) Pronator quadratus myotomy

Table 2. Pronation deformity classification and treatment options by Gschwind and Tonkin (18)

\begin{tabular}{|l|l|}
\hline Type & Treatment \\
\hline Type 1. Active supination beyond neutral & Surgery is unnecessary \\
\hline Type 2. Active supination to less than, or to neutral position & Pronator quadratus release. Flexor aponeurotic release \\
\hline Type 3. No active supination, free passive supination & Pronator teres transfer (Brachioradialis re-routing) \\
\hline Type 4. No active supination, tight passive supination & $\begin{array}{l}\text { Pronator quadratus and flexor aponeurotic release (Pronator teres } \\
\text { myotomy/lengthening+Brachioradialis re-routing) }\end{array}$ \\
\hline
\end{tabular}

of elbow flexor muscles/tendons, releasing the contracted soft tissues, separating the flexor-pronator muscle group from the adhesion point and shifting them distally. Overzealous release of the flexors should be avoided in order to prevent loss of elbow flexion.

\section{Forearm pronation deformity}

Forearm pronation is usually caused by spasticity of both the pronator teres and pronator quadratus muscles. Severe deformity causes a reverse-grasp posture, reaching for objects with the ulnar side of the hand positioned superiorly and the radial side of the hand inferiorly. It significantly limits the functions of the hand (13). Interosseous membrane contracture, secondary curvatures at the radius and ulna and dislocations at the radius head-especially in the posterior direction- may develop as a result of longlasting pronation contractures $(6,14,15)$.

Both pronation and supination movements are needed for adequate functionality of the hand (6). Therefore, the ideal surgical method for treating pronation deformity in patients with cerebral palsy must aim at restoring the active supination movement without compromising the existing pronation movement.

The surgical methods used to restore the pronation deformity can be classified in two groups. In the first group, the pronator contracture is released as a secondary benefit of a procedure which originally aims at restoring another deformity: flexor/pro- nator release or transferring flexor carpi ulnaris (FCU) to the wrist extensors. In the second group are the surgical methods directly aimed at the release of pronation contracture: pronator teres myotomy or lengthening (Figure 1a), pronator quadratus myotomy (Figure 1b), transfer of pronator teres to the wrist extensors and transfer of the FCU tendon to brachioradialis tendon insertion.

Pronator release only versus release with active tendon transfer in the treatment of pronation deformity is still a subject of discussion. Removal of the deforming force causing pronation deformity may imrove supination. However, it is generally reported that an active transfer is needed to further augment supination.

Gschwind and Tonkin have defined four types of pronation deformity and recommended treatment methods for each one, shown in Table 2. In our practice, we are using a modified version of this classification and treatment algorithm having included Brachioradialis re-routing technique for Type 3 and Type 4 cases.

Taking these principles into account, the techniques used in the surgical treatment of pronation deformity can be summarized as follows:

FCU $\rightarrow$ ECRB transfer: As a classical method, defined by Green, and generally used to increase the wrist extension, this is transfer of the flexor carpi ulnaris tendon to the extensor carpi radialis tendon. The primary target of this technique is to restore wrist 

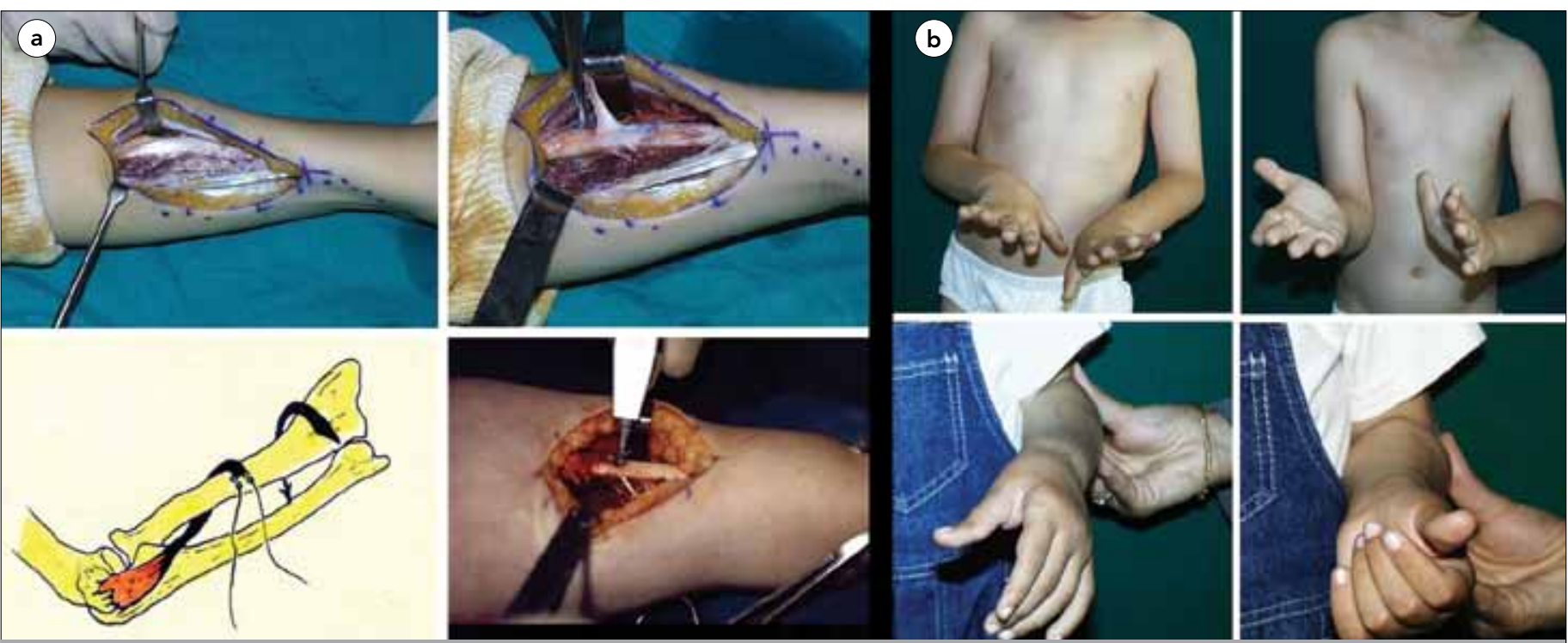

Figure 2. Pronator teres re-routing-Surgical technique: The forearm is brought to maximum supination and the pronator insertion at mid-1/3 radius is palpated. An approximately $3 \mathrm{~cm}$ incision is made in this area, the pronator teres insertion is found between the brachioradialis and ECRL tendons. Pronator teres tendon is stripped off the radius with $2 \mathrm{~cm}$ of periosteum. The interosseous membrane is dissected extra-periosteally proximal to the original insertion point. The pronator teres tendon is passed in a volar-dorsal direction through this window. The tendon is reinserted on the lateral aspect of the radius close to the original insertion point using classical techniques or suture anchor. Alternatively, the pronator tendon is $Z$ lengthened, the distal tendon slip is passed from dorsal to volar and then sutured to the proximal tendon. Postoperatively, an above elbow splint is applied, keeping the elbow at 45-90 degrees flexion and the forearm in 45-60 degrees supination for 4-5 weeks.

b) Pronator teres re-routing-Sample Case : Preoperative (above) and postoperative (below) active supination and protected active pronation views of a 5-year-old patient with cerebral palsy with supination deficit on the left forearm

extension. As a secondary benefit, the forearm gains substantial active supination. This additional advantage is documented in certain biomechanical studies (16).

Pronator Teres Rerouting: This procedure was first described by Sakellarides et al. (17). Later, Strecker et al. (14) and Gschwind et al. (18) published their results. Van Heest et al. (19) mechanically demonstrated on cadavers the improvement in supination via rerouting the pronator teres around the radius (Figure 2).

Brachioradialis re-routing: Described by Özkan et al. (20): This technique is used to correct forearm pronation deformity and restore active supination. Adequate active supination is achieved by altering the direction of the brachioradialis (re-routing). Since the pronator teres muscle, which is the major pronator muscle of the forearm, is not used as a motor, the forearm pronation is not disturbed. In a biomechanical study, Cheema et al. (16) have demonstrated that brachioradialis rerouting is the second best technique when compared with other methods (Figure 3).

Transfer of the brachialis muscle to the re-routed biceps tendon: This is an alternative technique which can be used in restoring forearm supination. It can be performed especially in the absence of a suitable motor tendon, and also is an option when there is a need to decrease the excessive flexion at the elbow (Figure 4). In a recent study, we reported on four patients who underwent a brachialis rerouting supinatorplasty. Active supination increased in two $\left(60^{\circ}\right.$ and $\left.50^{\circ}\right)$, minimally increased in one $\left(5^{\circ}\right)$, and did not change in one patient (21).

Other surgical techniques used in repairing the pronation deformity: Active increase in forearm supination can be expected by combining pronator teres release with passing the flexor carpi ulnaris around the ulnar side of the forearm and transferring it to $\mathrm{ECBR}$ or BR tendons. By transferring pronator teres to ECRB tendon, the pronator dominance over the forearm is broken. This force can be transferred to the weak wrist or finger extensors (22).

\section{Wrist}

Wrist and finger flexion deformities are among the most common problems in patients with spastic palsy (23). The flexion deformity of the wrist is caused by the wrist flexors, especially the flexor carpi ulnaris. Also, spastic finger flexors worsen the situation.

When the wrist is flexed, the finger flexors present substantial dysfunction especially during grip. Lengthening the wrist flexors decreases the flexor dominance on the wrist. This provides a mechanical advantage for the extensor muscle group. If the wrist extensors are not strong enough to balance out this flexor dominance, they may be actively supported by tendon transfers.

Prior to the transfer for the augmentation of the wrist extensors, the spasticity on the extrinsic finger flexors should be assessed. When the wrist is at the neutral position, the spastic finger flexors will be mechanically advantageous. The patient cannot loosen the clenched fist, which precludes grip. In such conditions, lengthening of the finger flexors must be included in the surgery plan. Loss of active extension requires correction with a tendon transfer.

\section{Wrist Flexion Deformity}

There are several drawbacks of having the wrist at flexion constantly: 1) Flexed wrist creates a mechanical disadvantage for the flexor muscles and reduces the grip power. 2) Especially in patients with deficient stereognosis, the coordination of hand movements may be maintained visually. With the flexion posture 

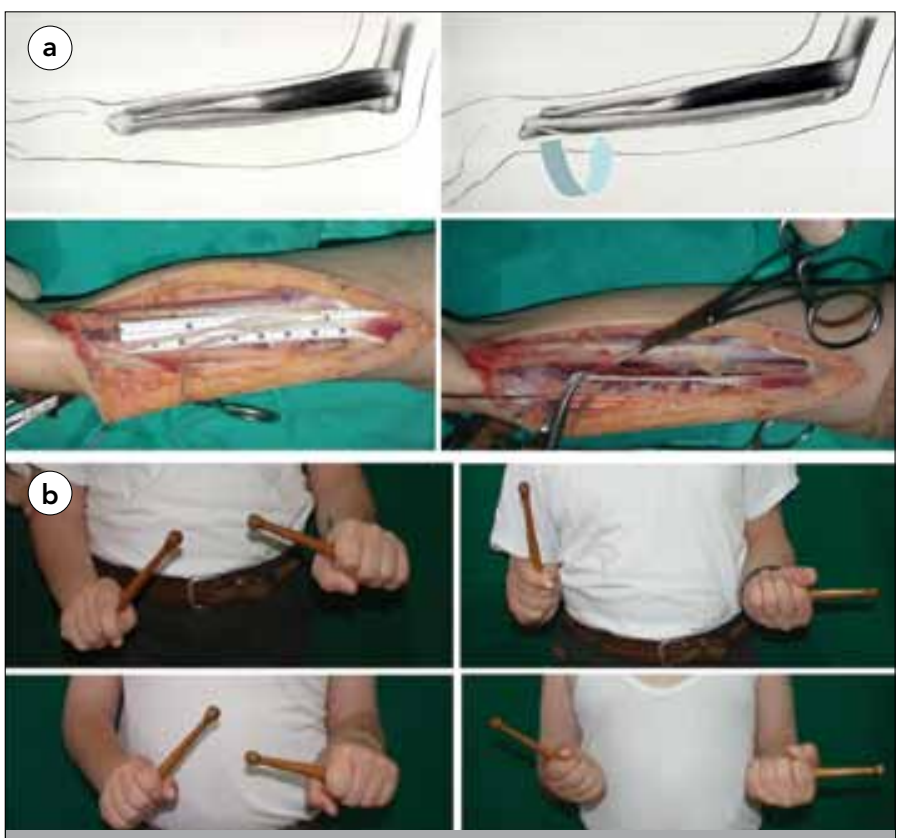

Figure 3. a) Brachioradialisre-routing - Surgical technique: An incision is made on the distal volar -radial aspect of the forearm, and the brachioradialis muscle-tendon unit is exposed. The radial artery and the radial nerve branch are retracted. The brachioradialis muscle and tendon are dissected and prepared for transfer. A very important step to be taken in the meantime is to isolate the muscle from all the surrounding fascial connections. Otherwise, the excursion of the muscle will not be adequate. The free end of the tendon that is detached and separated from the insertion point is passed beneath the flexor pollicis longus muscle and taken volarly from dorsal through the interosseous space. The tendon is re-routed extraperiostally around the radius while preserving the radial artery. The tension is adjusted while the forearm is held at neutral and the original length of the tendon is preserved. The tendon is re-inserted to the radius via classical methods or with a suture anchor. b) Brachioradialis re-routing-Sample Case: A 12-year-old cerebral palsy patient with lack of supination in the left forearm. Preoperative (above) and postoperative (below) views show active supination and preserved active pronation of the wrist, the fingers remain in the inward segment of the hand which impedes visualization. 3) The aesthetic appearance of the wrist at flexion may disturb the patient and the family members. 4) In case of severe flexion, there may be lesions on the volar side skin of the wrist.

The wrist plays a key role in movements of the hand. Even when there is no active movement on the fingers, flexion and extension can be made with the tenodesis effect. A moving wrist provides at least $25 \%$ of hand function. Therefore, wrist arthrodesis should be performed only in severe deformities, where treatment with dynamic methods fails. In cerebral palsy surgery, a mobile wrist is always among the priorities.

Wrist deformity may develop due to flexor tendon tightness, inadequate wrist extensors, contracture of the wrist volar capsule or a combination of these factors.

\section{Wrist and Finger Flexor Tightness and Treatment}

Wrist flexion deformity is generally caused by the spasticity of the flexor carpi ulnaris tendon. In some patients, flexor carpi radialis and Palmaris longus tendons are also spastic. Tenseness on the finger flexors, if any, impedes full extension of the wrist and conduces to deformity. Before a transfer to bring the wrist to extension, factors impeding the passive joint movement span must be eliminated.

The treatment algorithm below may facilitate the treatment preferences for maintaining passive movement of the wrist:

Lengthening of the wrist flexor tendons: The muscle which prevents passive extension of the wrist most is the spastic flexor carpi ulnaris. Furthermore, the spasticity of this muscle may cause ulnar deviation of the wrist. Extensor carpi ulnaris may create a strong ulnar deviation on the wrist during pronation and also a flexion deformity of the wrist when it is in volar subluxation. In the latter case, the extensor carpi ulnaris tendon can be transferred to the extensor carpi radialis brevis tendon. In moderate
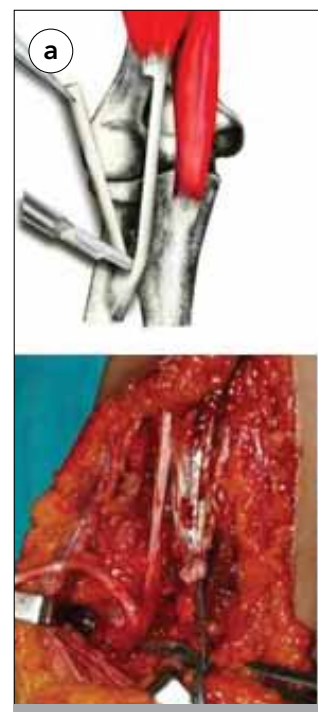
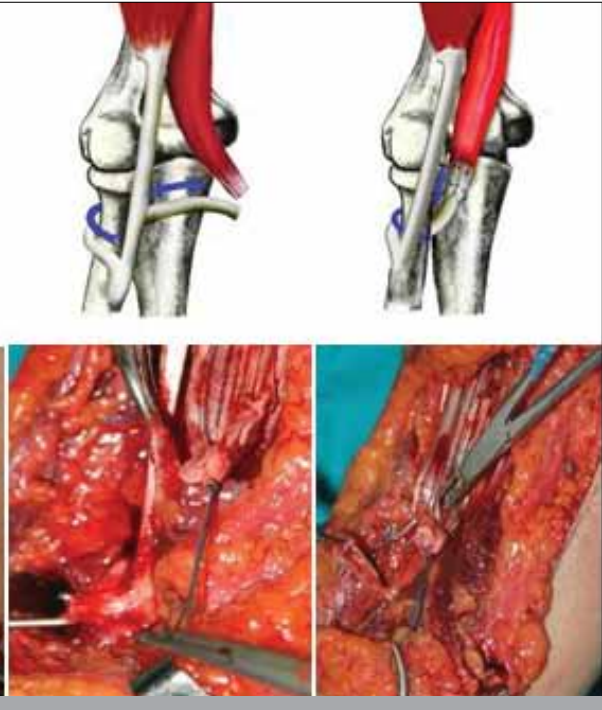

Figure 4. a)Transfer of the brachialis muscle to the re-routed biceps tendon-
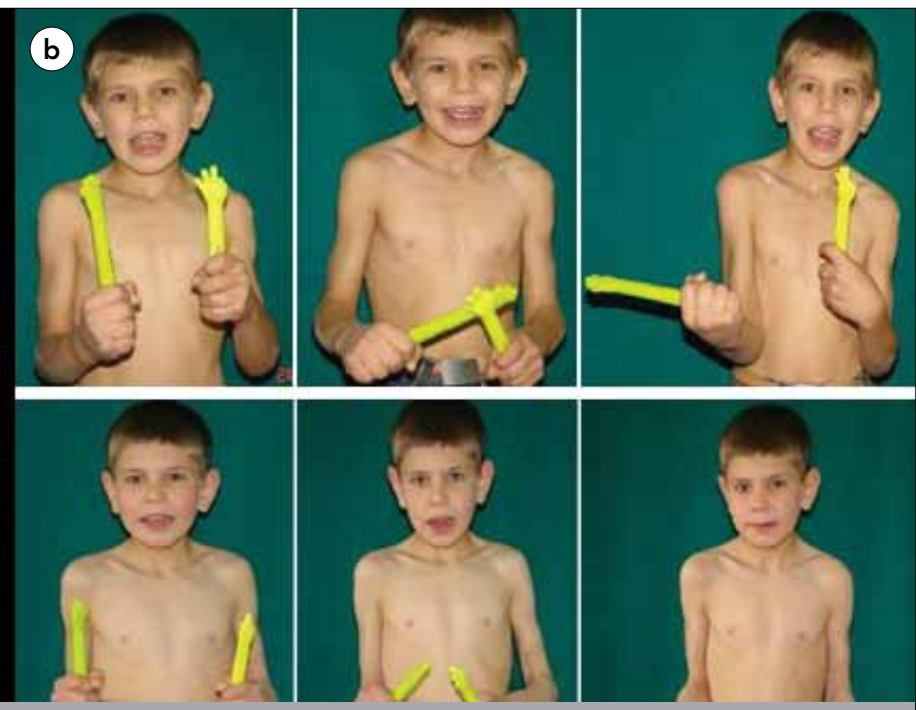

- Surgical technique: The brachialis muscle is completely separated from its the insertion point and released proximally. The biceps tendon is split longitudinally, while the insertion is left intact. The biceps slip on the radial side is re-routed around the radius neck. By fixing it to the musculo-tendinous segment of the brachialis muscle prepared before, the supinatorplasty is completed. b)Transfer of the brachialis muscle to the re-routed biceps tendon-Sample Case: Preoperative (above) and postoperative (below) active supination and preserved active pronation in a 10-year-old patient with cerebral palsy with lack of supination in the left forearm. 
cases, only fractional or Z plasty lengthening of the flexor carpi ulnaris tendon may be sufficient. If an active wrist extension is desired, the flexor carpi ulnaris tendon can be transferred to wrist extensor tendons. The palmaris longus tendon can be separated from the distal insertion point and be used for transfer (e.g. to the thumb extensor tendon). Although the flexor carpi radialis tendon can be used in tendon transfers, only lengthening of this tendon is recommended since releasing both wrist flexors may lead to hyperextension deformity, which may create complications especially when the finger extension is not adequate.

Release of finger flexor tendons: All flexor tendon lengthening techniques result in a decrease in the power of the flexor tendons. However, this can be compensated by the wrist, strengthening the grip during extension. While fractional lengthening creates minimal strength loss, the superficialis-to-profundus (STP) tendon transfer procedure may cause severe strength loss. The effect of Z-lengthening stands between these two procedures.

Other bone procedures like proximal row carpectomy, and wrist arthrodesis are not recommended on functional hands. These methods may be performed on rather severe cases for hygieneand cosmesis-related concerns.

i) Fractional Tendon Lengthening has minimal excessive lengthening risk and minimal negative effect on the grabbing power of the fingers, therefore it is preferred in well-functioning hands. A longitunal incision on the mid $1 / 3$ of the volar forearm is sufficient if only fractional lengthening is planned. Two transverse tenotomies are made on the musculotendinous region of the tendon to be lengthened. The most distal tenotomy must be at least $2 \mathrm{~cm}$ away from the most distal point of the musculotendinous junction, and there must be a minimum $1 \mathrm{~cm}$ distance between the tenotomies. Only the tendinous part of the musculotendinous connection should be cut and the muscular part must be kept untouched (Figure 5).

If passive extension of the fingers is still limited despite full flexion of the wrist, then possibly fractional lengthening will not be adequate and one of the other two techniques will be required.

ii) Tendon Z-lengthening: This method can be used in cases where fractional lengthening is inadequate. It is especially used in FPL lengthening. Here, the most important criterion is lengthening the tendon by $0.5 \mathrm{~cm}$ for each degree of joint opening desired. The tendon is cut at the radial aspect on one side and ulnar on the other. After the lengthening, the tendon ends are fixed with Pulvertaft weave or end-to-side technique. If the lengthening is performed on the thumb, fixation is performed when the wrist is at neutral and the MP and IP joints are at mild flexion. When the wrist is at extension, the thumb must be touching the second finger. Furthermore, the thumb must be out of the palm with the flexion of the wrist.

iii) Superficialis-to-profundus procedure (STP): This procedure must be performed on dysfunctional hands with severe flexion contracture as it causes considerable loss in grip power (Figure 6).

Flexor/Pronator slide: Pronator teres can be detached from its origin, the medial condyle, and moved distally. This procedure, called the flexor-pronator slide (Figure 7) is usually performed on
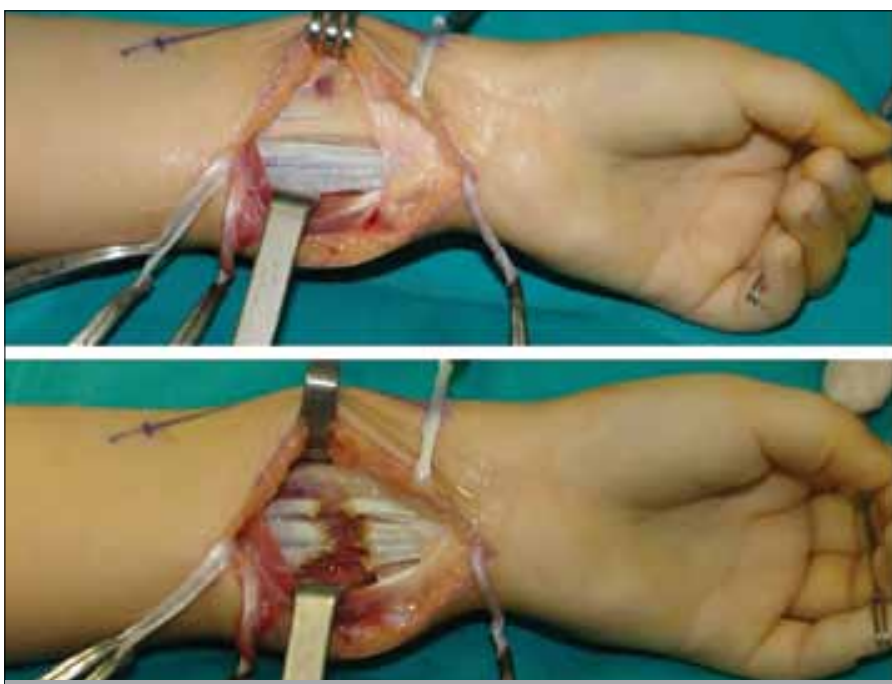

Figure 5. Fractional tendon lengthening
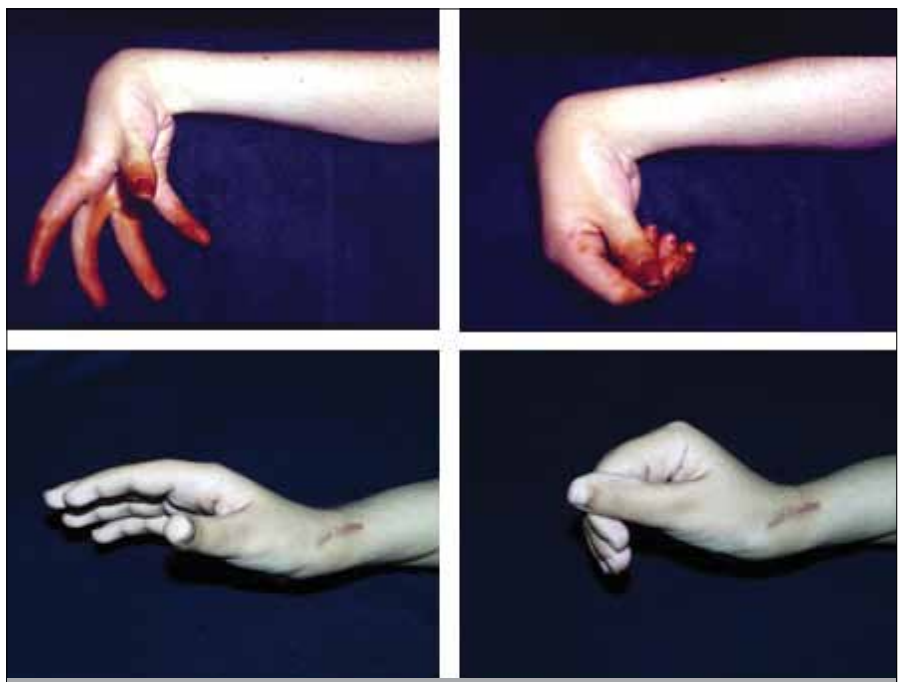

Figure 6. Superficialis to profundus tendon transfer: Preoperative (upper row) and postoperative(lower row) views are shown

patients with CP sequela and central hemiparesis, who have severe flexor dominance in the elbow, wrist and fingers. The procedure may also be performed to involve all the flexors, originating from the pronator/flexor common origin at the medial epicondyle level (24).

In addition, proximal row carpectomy can shorten the forearm by approximately $1 \mathrm{~cm}$ and maintain a passive dorsiflexion increase of $25^{\circ}$ on the wrist.

\section{Extension Loss of the Wrist and Its Management}

After elimination of the factors preventing passive extension of the wrist, active extension of the wrist must be achieved. The surgical classification by Zancolli (6) can serve as a reference point for the active tendon transfer:

The cases in Group 1 can have full finger extension with less than $20^{\circ}$ wrist flexion. In this group, usually the flexor carpi ulnaris muscle is spastic, and lengthening of this muscle solves the problem in most cases. 

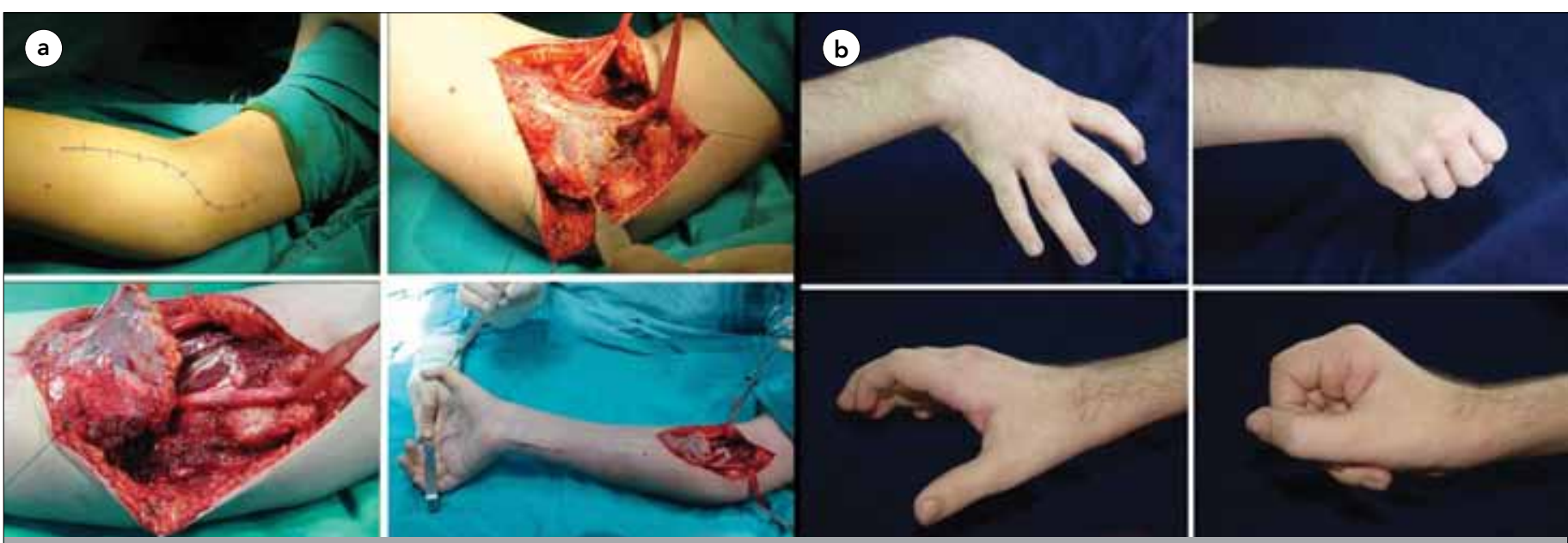

Figure 7. a. Flexor/Pronator Slide: Surgical technique b)Flexor/Pronator Slide: Sample Case: Preoperative (upper row) and postoperative (lower row) views of a patient with spasticity in the wrist and fingers
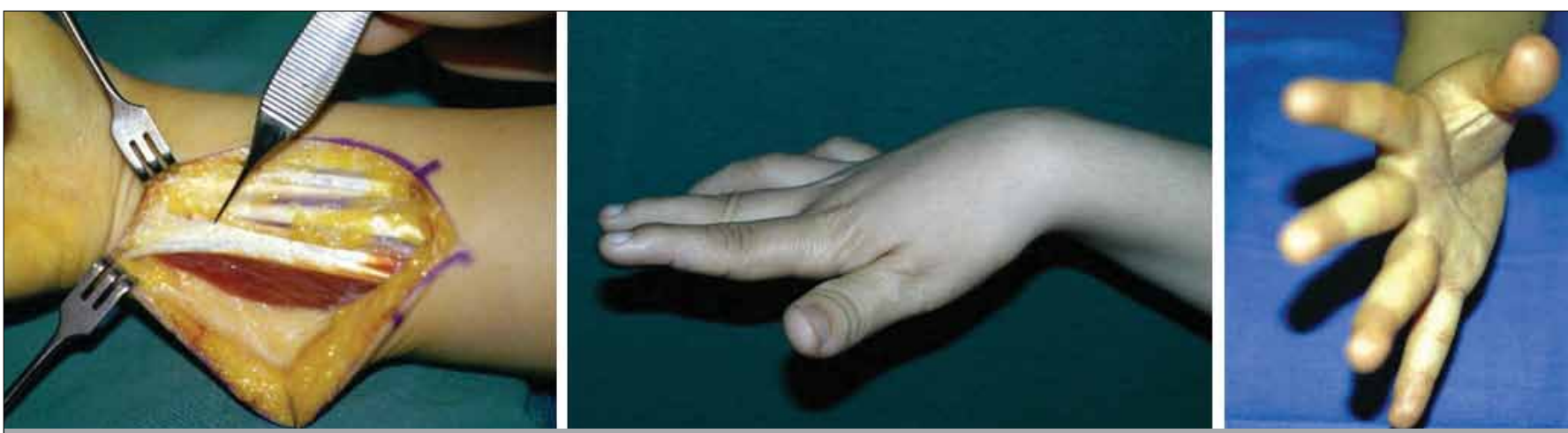

Figure 8. Green transfer: The FCU tendon is exposed with an incision on the volar ulnar side of the distal forearm. The FCU tendon is released from insertion on the pisiform bone. The ECRB and ECRL tendons are exposed with a second incision on the dorsal aspect of the wrist. A subcutaneous tunnel is prepared on the ulnar side of the forearm, between the two incisions. The FCU tendon is taken through this tunnel and attached to the recipient tendon with Pulvertaft weave. The tension is adjusted while the transferred tendon is under maximal tension and the wrist is at neutral mild dorsiflexion. The wrist should have a passive flexion of $20^{\circ}$, otherwise, the anastomosis is tense ${ }^{11}$. The figure shows preoperative (middle) and postoperative (right) views of a patient who underwent Green transfer

In Group 2, the active finger extension can be provided only with a wrist flexion greater than $20^{\circ}$. In Subgroup $2 A$, there is weak wrist extension when the fingers are in flexion. In Subgroup 2B, on the other hand, there is no wrist extension at all. The latter group needs supportive transfer procedures to maintain the wrist extension after flexor release.

The transfers mostly used for wrist extension are: FCU $\rightarrow E C R B$, $\mathrm{ECU} \rightarrow \mathrm{ECRB}, \mathrm{PT} \rightarrow \mathrm{ECRB}, \mathrm{BR} \rightarrow \mathrm{ECRB}$ and $\mathrm{FDS} \rightarrow \mathrm{ECRB}$. If a more radial deviation of the wrist is required, these transfers should be made to the ECRL tendon. Additionally, the $\mathrm{FCU} \rightarrow \mathrm{ECRB}$ transfer performed to maintain wrist extension actively adds to the forearm supination (Figure 8).

The cases in Group 3 do not have active finger extension. In general, there is severe involvement. Transfer to the finger extensors (e.g. FCU $\rightarrow E D C$ ) is needed after release of the contractures in the flexor muscles.

\section{Surgical techniques commonly used in wrist extension insuf- ficiency treatment:}

1. Green Transfer (Flexor carpi ulnaris tendon $\rightarrow$ Extensor carpi radialis brevis tendon transfer): Technical details of this method are summarized in Figure 9.
2. Extensor carpi ulnaris tendon $\rightarrow$ Extensor carpi radialis brevis tendon transfer: This transfer is performed on patients who have sufficient wrist extension and whose wrists become flexed during grip under the influence of finger flexors. This transfer must always be performed together with fractional lengthening of FCU muscle. It cannot be performed simultaneously with wrist flexors $\rightarrow$ wrist extensors transfer. Otherwise, extension deformity may develop $(25,26)$.

3. Pronator teres tendon $\rightarrow$ Extensor carpi radialis brevis tendon transfer: This technique is suitable for patients whose FCU tendon is dysfunctional or used as a motor for another transfer. However, due to the limited excursion of pronator teres, the wrist movements are reduced. Since the pronator teres is often spastic, this transfer provides benefit especially in tenodesis form. The PT tendon, released at its insertion at mid-1/3 forearm, is transferred to ECRB tendon.

4. Brachioradialis tendon $\rightarrow$ Extensor carpi radialis brevis tendon transfer: The brachioradialis tendon can be used for wrist extension, when the other motors are not suitable for transfer. However, as stated above, the fascial connections around the muscle must be completely released to provide sufficient excursion for the brachioradialis muscle. 
5. Transferring flexor carpi ulnaris $\rightarrow$ Extensor digitorum communis tendons: As explained above, the reason for the finger extension and the difficulty in releasing the hand may either be the contracture on the volar structures or the weakness of the finger extensors. Flexor carpi ulnaris transfer may support the finger extensors. The superficial flexor tendons of the third and fourth finger can also be used to strengthen the finger extensors.

Technique: Similar to Green transfer, the FCU is exposed with an incision on the forearm volar-ulnar side. The FCU tendon is passed on the ulnar side of the forearm subcutaneously. On the wrist extensor side, the EDC tendons are exposed with an incision of $4-5 \mathrm{~cm}$ on the $4^{\text {th }}$ extensor compartment. The FCU tendon is taken through the subcutaneous tunnel and woven side-byside with Pulvertaft weaving. The tension of the tendons is adjusted accordingly to keep the MP joints at neutral position and the IP joints at mild flexion. The hand is immobilized for four weeks -fingers are kept as explained above, while the wrist is held at $30^{\circ}$ extension $(12,25,26)$.

The treatment algorithm we are following in the surgical restoration of the problems related to finger and wrist spasticity is summarized in Tables $3 a$ and $b$.

\section{Surgical treatment of finger and thumb deformities}

\section{"Swan Neck" Deformity}

The hyperextension on the PIP joint and flexion deformity of the DIP joint is known as the "swan neck deformity". Its etiology is created by the tenodesis effect of the EDC tendons when the wrist is in a spastic flexion posture and the hyperactivity of the intrinsic hand muscles. Although swan neck deformity is commonly seen in cerebral palsy, surgical intervention is needed only when the fingers are locked in the hyperextension position and there are progressive PIP joint extension deformities which cannot be prevented with splinting (27).

In cerebral palsy, swan neck deformity is caused by the relatively shorter central slip. The shortness is relative and does not inter- fere with flexion of the PIP joint. Both the spasticity of the intrinsic muscles and the hyperactivity of the extrinsic finger extensors play a role in the patho-physiology of the tightness on the central slip (12). The high tension, generated by the spasticity of the intrinsic muscles, is transferred to the central slip via medial interosseous bands. This creates hyperextension in the PIP joint. In case of a loosening on the retinacular ligament, the extensor mechanism gets subluxed towards the dorsal aspect. With the additional loosening of the volar plate, the hyperextension of the PIP joint increases. Recurvatum deformity is observed. Meanwhile, the subluxation of the extensor mechanism towards the dorsal leads to relative insufficiency on the lateral bands. DIP joint flexion occurs.

Furthermore, patients with insufficient wrist extensors try to compensate the wrist extension function with the extrinsic finger extensors. Within the system explained above, the increased load on the central slip augments the severity of the swan neck deformity. In addition, after lengthening operations of the superficialis tendons, the swan neck deformity may become more evident.

The MP joint flexion observed in swan neck deformity is explained as follows: The wrist and finger joints make up a kinetic chain. The weakest rings of this chain are the PIP joint and the MP joint, respectively. The extension on the PIP joint leads to flexion on the proximal and distal joints. Moreover, these forces cause a subluxation of the MP joint in the volar direction. Maintaining flexion of the PIP joint prevents the deformation in the finger. In this case, the normal axis of the finger is preserved. Based on this rationale, the following treatment methods are recommended for the treatment of swan neck deformity (12):

1. Decreasing the load on the central slip by cutting the ligaments connecting the intrinsic muscles to the central slip.

2. Keeping the lateral bands more volarly, by shortening the retinacular ligament

3. Preventing the load on the central slip by reattaching the extensor tendon on the proximal phalanx instead of the central slip

\section{Table 3. Test active digital extension with wrist in neutral, b) Test active range of moton in the wrist}

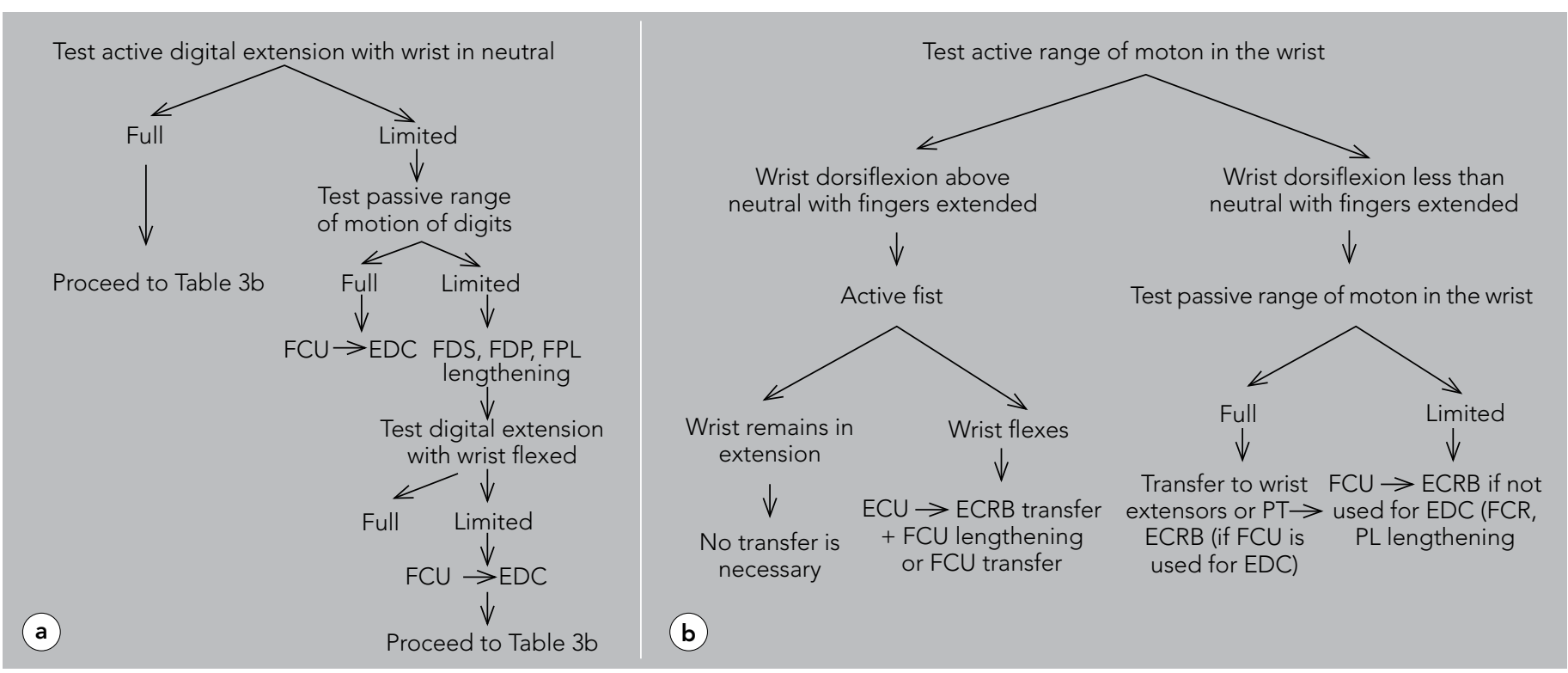


4. Limiting joint hyperextension by placing a tendon graft on the volar side of the PIP joint

5. Arthrodesis of the PIP joint at flexion

6. Preventing the joint extension by using the flexor digitorum sublimis tendon or by performing volar capsulorraphy: sublimis tenodesis (Figure 10).

7. Advancing the interosseous muscles (13)

8. Ulnar motor neurectomy

9. Sling procedure (6)

10. Flexion osteotomy on the metacarpal

\section{Surgical Treatment of "Thumb-in-Palm" Deformity:}

"Thumb-in palm" deformity is one of the most common and complicated deformities of cerebral paralysis, and is caused by spasticity of the thumb adductor and flexor muscles. When the thumb is locked inside the palm, it cannot function. Also it hinders the grabbing function of the other fingers.

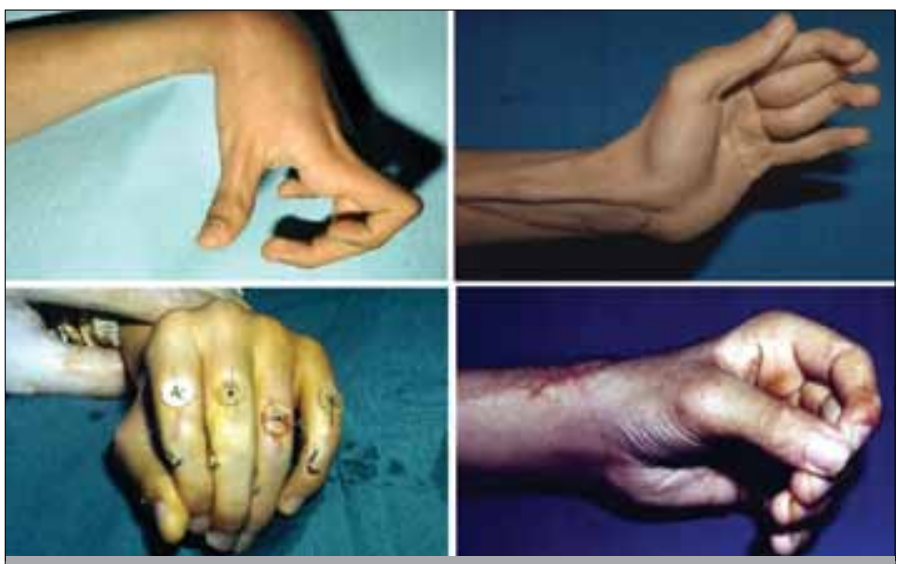

Figure 9. Correction of swan neck deformity with sublimis tenodesis technique: Preoperative view of a 13-year-old patient with severe spasticity on the left hand (left-above)- Swan neck deformity occurred as a result of the "over correction" seen after lengthening and tendon transfer (right-above)- Immediate (left-below) and long-term (right-below) results after sublimis tenodesis surgery
Parallel to the evolution of cerebral paralysis surgery, thumb operations have developed into dynamic soft tissue procedures, rather than static bone operations. Authors, including Goldner, Inglis and Keats, have succeeded in forming mobile thumbs by maintaining the muscular balance via tendon transfers and selective joint arthrodeses (28).

The objectives of the surgical treatment of thumb-in-palm deformity are to generate a strong lateral pinch on the mid-phalanx of the second middle finger -at fist form- and to maintain sufficient radial abduction during grabbing (29). The major challenge of the treatment is the multifactorial quality of the deformity. With the aim of making a systemic definition of the deformity and proposing a treatment plan, House (28) and Sakellarides (30) have formulated two different classification systems (Table 4).

The etiology of the thumb deformity is multifactorial. There are four main reasons for this form of deformity: 1) Spasticity of the

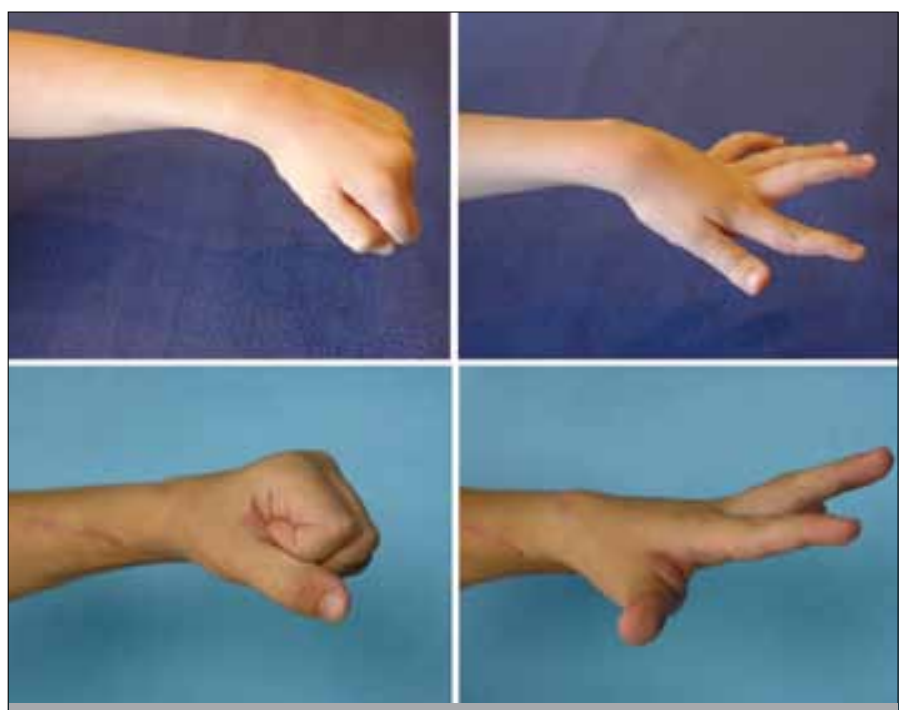

Figure 10. Augmentation of abductor and extensor tendons: Preoperative (upper row) and postoperative (lower row) views of the patient

Table 4. Surgical classifications of thumb-in-palm deformity

\begin{tabular}{|c|c|c|}
\hline \multicolumn{3}{|c|}{ House classification } \\
\hline Type & Deformity & Reason \\
\hline Type I & Simple metacarpal adduction & Spastic adductor and first dorsal interosseous muscles \\
\hline Type II & $\begin{array}{l}\text { Simple metacarpal adduction+MP flexion } \\
\text { deformity }\end{array}$ & $\begin{array}{l}\text { Spastic adductor, first dorsal interosseous and spastic flexor pollicis } \\
\text { brevis muscles }\end{array}$ \\
\hline Type III & $\begin{array}{l}\text { Simple metacarpal adduction+MP hyperextension } \\
\text { deformity/instability }\end{array}$ & $\begin{array}{l}\text { Spastic adductor, first dorsal interosseous and EPB } \\
\text { muscles+hyperextensible MP joint }\end{array}$ \\
\hline Type IV & $\begin{array}{l}\text { MP and IP joint flexion deformity+simple } \\
\text { metacarpal adduction contracture }\end{array}$ & $\begin{array}{l}\text { Spastic adductor andfirst dorsal interosseous+flexor pollicis longus } \\
\text { muscles }\end{array}$ \\
\hline \multicolumn{3}{|c|}{ Sakellarides classification } \\
\hline Type & Deformity etiology & Treatment \\
\hline Type I & Weak EPL & Transferring PL or FCR to EPL \\
\hline Type II & $\begin{array}{l}\text { Spastic or contracted intrinsic muscles of the } \\
\text { thumb }\end{array}$ & $\begin{array}{l}\text { Thenar muscles- } 1 \text {. Releasing dorsal interosseous muscle or the } \\
\text { carpal tunnel+releasing the } 1^{\text {st }} \text { web skin, if contracted }\end{array}$ \\
\hline Type III & Weak abductor pollicis longus & Rerouting the abductor around the FCR \\
\hline Type IV & Spastic or contracted FPL & Z-lengthening of FPL \\
\hline
\end{tabular}


adductor and flexor muscles, 2) Flaccid paralysis on the extensors and abductors, 3) Hypermobile metacarpophalangeal joint and 4) Contracture on the first web skin.

Assessing each of these points in the preoperative term would obviously facilitate the formulation of a surgical plan. The assessment involves physical examination, electromyography and diagnostic nerve blocks. Usually, the increased tonus of the muscles and the thumb's position at rest show which muscles are causing the deformity.

a. In the deformity related to the spasticity of the thenar muscles, there is flexion in the metacarpophalangeal joint and extension in the interphalangeal joint;

b. Deformity related to the spasticity of flexor pollicis longus muscle is concomitant especially with interphalangeal joint flexion and different degrees of flexions at the metacarpophalangeal joint;

c. The involvement of adductor pollicis muscle leads to flexion of the metacarpophalangeal joint and adduction of the first metacarpal bone towards the center of the palm;

d. The involvement of the opponens pollicis muscle or the first dorsal interosseous muscles leads to the adduction of the metacarpal bone in line with the palm; and thus the thumb gets trapped in the web space.

I. Treatment of adductor and flexor muscle spasticities: Release of adductor pollicis, first dorsal interosseous and flexor pollicis brevis muscles can be performed as muscle myotomy at the origin, insertion or between the two (10). Release at insertion is often avoided since it removes the entire functionality of the muscle. Release at origin, on the other hand, preserves the functionality to a certain extent via the adhesion of the muscle to the adjacent tissues. During muscle myotomy the muscle is kept in a tense position, the tendinous part is cut, while the muscle fibers are protected.

\section{Surgical techniques}

a. Adductor / Flexor Release: An incision parallel to the thenar crease is made. The dissection is continued up to the thenar muscles. Flexor pollicis brevis and abductor pollicis brevis are isolated at their origin on the transverse carpal ligament. They are released through the ligament. Meanwhile, the proximal phalanx is brought to extension to facilitate the radial movement of the muscles. With proper splinting in the postoperative period, these muscles attach to their new location. If spastic, the adductor muscle is released during the same session. If the muscle is to be released from its origin, the flexor tendons of the second and third fingers and the neurovascular structures are retracted and stripped off over the third metacarpal bone. If the muscle is to be released from the insertion point, it is followed to the radial side and cut at the tendinous insertion point. In cases where the adductor muscle is to be released without touching the flexor muscles, the adductor muscle is penetrated with an incision on the first web.

b. Releasing the dorsal interosseous muscle: An incision is made through the palpable ulnar border of the first metacarpal bone. The radial nerve branches and the EPL tendon are retracted. The first dorsal interosseous muscle is a bipennate muscle. Its origin is in the first and second metacarpals. Its origin in the first metacarpal is released, while the segment in the second metacarpal is left untouched. This untouched segment helps the flexion and abduction of the second finger. If the incision is taken to the MP joint distally, the abductor can also be released through this incision.

c. FPL tendon lengthening: The FPL spasticity seen in Type IV deformity is treated with fractional lengthening or Z-lengthening on the FPL tendon proximal to the wrist, similar to the wrist flexors.

II. Supporting the abductor and extensor tendons: The tendon reinforcements and their objectives can be summarized as: APL -for the abduction of the first metacarpal, EPB -for the extension of the proximal phalanx and EPL for the extension of the distal phalanx. The reinforcement can be performed in following forms: tendon plication, tendon transfer or fixing the tendon to a bone-periosteum or to another tendon at a proper tension (tenodesis):

1) Tendon transfers: With the aim of maintaining the thumb extension and taking the thumb out of the palm, transferring BR, PL, ECLR, ECRB, FCR, FCU and FDS tendons were recommended by several authors $(10,11)$. APL is the most important tendon effective on the carpometacarpal joint. Taking the APL tendon out of the first compartment and moving it volarly provides a mechanical advantage for the abduction of the first metacarpal. In addition, suturing the PL tendon (end-to-side) to the volarly rerouted APL tendon may increase the abduction (28). If the extension vector is to be preserved, the same transfer can be performed by protecting the pulley of the first compartment. As an alternative, the APL is cut and its distal end is reinforced with an appropriate motor, while the proximal end is transferred to the EPB tendon (end-to-side) under tension. In this way, both metacarpal abduction and proximal phalanx extension are maintained.

In cases where an appropriate motor muscle cannot be found for transfer, the APL is cut and its distal end is re-routed towards the volar side. Then it is fixed end-to-side to the FCR tendon. This may create a tenodesis effect and maintain metacarpal abduction.

Figure 10 shows an example, where the above mentioned techniques are combined to reinforce the thumb abductor and extensor tendons.

\section{2) Shortening $A P L$ and $E P B$ tendons via plication}

3) EPL Re-Routing: The EPL tendon, which passes around the Lister's tubercle, also has an adductor effect due to its path. Therefore, procedures radializing this route are expected to have a positive effect on abduction. Goldner et al. (26) removed the EPL tendon from its fibro-osseous channel, creating a new pulley over the radial styloid and moving the route of the tendon radially. Later, Manske (31) took the EPL tendon through 

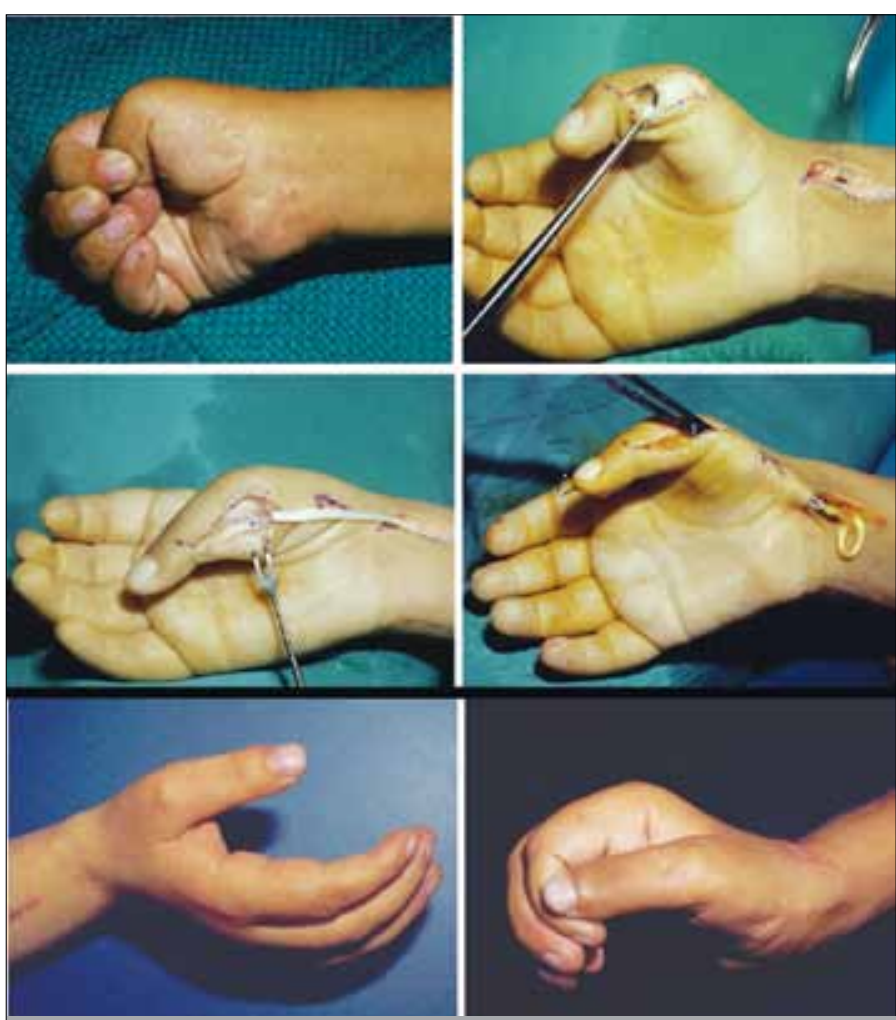

Figure 11. Correction of thumb-in-palm deformity with FPL abductorplasty: Preoperative view and surgical technique b) Postoperative view of the patient shown in Figure 11a

the first dorsal retinacular compartment. This method eliminated the need for a new pulley. Modifying the method further, Rayan and Saccone (32) transected the EPL tendon proximal to the retinaculum, then anastomosed the distal EPL tendon slip taken through the first dorsal compartment, with the proximal slip. The authors reported that they maintained satisfactory abduction.

4) FPL Abductorplasty (Figure 11): The spastic FPL tendon to be released is cut on the proximal phalanx. The distal segment is used for the stabilization of the IP joint in children. The proximal segment is pulled through a second incision on the wrist. A second subcutaneous tunnel is opened further radially and the tendon is radialized.

III. Hypermobile MP Joint: The stability of the metacarpophalangeal joint is crucial for the reinforcements on the EPL or EPB tendons. If the joint has a hyperextension exceeding $20^{\circ}$, reinforcement of these tendons will lead to hyperextension deformity of the MP joint. In order to prevent this, in such deformities where the MP joint is hyperextensible, capsulodesis or arthrodesis of the MP joint is needed. Capsulodesis can be attempted to avoid arthrodesis, especially in children younger than 13 (7). Filler et al. (33) have obtained long-term results by performing capsulodesis on 13 patients with cerebral palsy. According to their technique, the volar plate is cut and fixed to a further proximal position on the metacarpal, while the MP joint is kept at $30^{\circ}$ flexion.
MP joint arthrodesis is recommended when capsulodesis is insufficient. During the arthrodesis, the growth plate on the epiphysis is preserved and, by performing joint cartilage resection only, growth is not disturbed in young children (approximately 4-5 year-old) (8).

IV. Releasing the first web skin: Any contracture on the skin can be released by two- or four-flap Z-plasties.

\section{CONCLUSION}

Surgical management of the spastic upper limb in cerebral palsy requires meticulous evaluation and planning. It is important to know that upper extremity deformities are secondary manifestations of the cerebral injury. Therefore, in addition to evaluation of upper extremity function, consideration should be given to the intelligence and motivation of the patient, and voluntary use of the upper extremity. Prior to surgery, the overall level of function needs to be considered. This is also important for the patients and their families, who should know that surgery is aimed at improving the upper extremity deformity, and not the primary disorder. An appropriately indicated surgery can significantly contribute to upper extremity function.

Conflict of interest: No conflict of interest was declared by the authors.

\section{REFERENCES}

1. Bax M, Goldstein M, Rosenbaum P, Leviton A, Paneth N, Dan B, et al. Proposed definition and classification of cerebral palsy. Dev Med Child Neurol 2005; 47: 571-6. [CrossRef]

2. Dahlin LB, Komoto-Tufvesson Y, Salgeback S. Surgery of the spastic hand in cerebral palsy. Improvement in stereognosis and hand function after surgery. J Hand Surg 1998; 23: 334-9. [CrossRef]

3. Manske PR. Cerebral palsy of the upper extremity. Hand Clin 1990; 6 : 697-709.

4. Waters P, Van Heest A. Spastic hemiplegia of the upper extremity in children. Hand Clinics 1998; 14: 119-34.

5. Moberg IE. Reconstructive hand surgery in tetraplegia, stroke and cerebral palsy; some basic concepts in physiology and neurology. J Hand Surg 1976; 1: 29-34.

6. Zancolli EA, Zancolli ER Jr. Surgical management of the hemiplegic spastic hand in cerebral palsy. Surg Clin North America 1981; 61: 395-406.

7. Keats S. Surgical treatment of the hand in cerebral palsy. Correction of thumb-in-palm and other deformities. Report of nineteen cases. $J$ Bone Joint Surg 1965; 47: 274-84.

8. Mital AM, Sakellarides HT. Surgery of the upper extremity in the retarded individual with spastic cerebral palsy. Orthop Clin North America 1981; 12: 127-41.

9. Skoff H, Woodbury DF. Management of the upper extremity in cerebral palsy. J Bone Joint Surg 1985; 67: 500-3.

10. Goldner JL. Upper extremity tendon transfers in cerebral palsy. Orthop Clin North Am 1974; 5: 389-414.

11. Beach WR, Strecker WB, Coe J, Manske PR, Schoenecker PL, Dailey L. Use of the Green transfer in treatment of patients with spastic cerebral palsy: 17-year experience. J Pediatr Orthop 1991; 11: 731-6. [CrossRef]

12. Manske PR. Cerebral palsy of the upper extremity. Hand Clin 1990; 6: 697-709.

13. Carlson MG. Cerebral palsy. In: Green DP, Hotchkiss RN, Pederson WC, Wolfe SW editors. Green's Operative Hand Surgery $5^{\text {th }}$ ed. Pennsylvania: Churchill Livingstone; 2005. p.1197-234.

14. Strecker WB, Emanuel JP, Dailey L, Manske PR. Comparison of pronator tenotomy and pronator rerouting in children with spastic cerebral palsy. J Hand Surg 1988; 13: 540-3. [CrossRef] 
15. Pletcher DFJ, Hoffer M, Koffman DM. Nontraumatic dislocation of the radial head in cerebral palsy. J Bone Joint Surg 1976; 58: 104-5.

16. Cheema TA, Firoozbakhsh K, De Carvalho AF, Mercer D. Biomechanic Comparison of 3 Tendon Transfers for Supination of the Forearm. J Hand Surg 2006; 31: 1640-4. [CrossRef]

17. Sakellarides HT, Mital MA, Lenzi WD. Treatment of pronation contractures of the forearm in cerebral palsy by changing the insersion of pronator teres. J Bone Joint Surg Am 1981; 63: 645-52.

18. Gschwind C, Tonkin M. Surgery for cerebral palsy. Part I. Cassification and operative procedures for pronation deformity. J Hand Surg $\mathrm{Br}$ 1992; 17: 391-5. [CrossRef]

19. Van Heest $A E$, Sathy M, Schutte L. Cadaveric modeling of the pronator teres rerouting tendon transfer. J Hand Surg Am 1999; 24: 614-8. [CrossRef]

20. Özkan T, Tunçer S, Aydın A, Hoşbay Z, Gülgönen A. Brachioradialis re-routing for restoration of active supination and correction of forearm pronation deformity in cerebral palsy. J Hand Surg 2004; 29: 265-70. [CrossRef]

21. Ozkan T, Bicer A, Aydin HU, Tuncer S, Aydin A, Hosbay ZY. Brachialis muscle transfer to the forearm for the treatment of deformities in spastic cerebral palsy. J Hand Surg Eur Vol. 2012 Aug 22. [Epub ahead of print] [CrossRef]

22. Colton $\mathrm{CL}$, Ransford $\mathrm{AO}$, Lloyd-Roberts GC. Transposition of the tendon of the pronator teres in cerebral palsy. J Bone Joint Surg Br 1976; 58: 220-3.

23. Rayan GM, Young BT. Arthrodesis of the spastic wrist: J Hand Surg 1999; 24: 944-52. [CrossRef]
24. Inglis $A E$, Cooper W. Release of the flexor-pronator origin for flexion deformities of the hand and wrist and fingers in spastic paralysis $\mathrm{J}$ Bone Joint Surg Br 1966; 48: 847-57.

25. Goldner JL. Surgical reconstruction of the upper extremity in cerebral palsy. Instr Course Lect 1987; 36: 207-35.

26. Hoffer HM, Lehman M, Mitani M. Long-term follow up on tendon transfers to extensors of the wrist and fingers in patients with cerebral palsy. J Hand Surg Am 1986; 11: 836-40.

27. Swanson $A B$. Surgery of the hand in cerebral palsy and the swanneck deformity. J Bone Joint Surg Am 1960; 42: 951-64.

28. House JH, Gwathmey FW, Fidler MO. A dynamic approach to the thumb-in-palm deformity in cerebral palsy. J Bone Joint Surg 1981; 63: 216-25.

29. Tonkin MA, Hatrick NC, Eckersley JRT, Couzens G. Surgery for cerebral palsy. Part 3: Classification and operative procedures for thumb deformity. J Hand Surg 2001; 26: 465-70. [CrossRef]

30. Sakellarides HT, Mital AM, Matza RA, Dimakopoulos P. Classification and surgical treatment of the thumb-in-palm deformity in cerebral palsy and spastic paralysis. J Hand Surg 1995; 20: 428-31. [CrossRef]

31. Manske PR. Redirection of extensor pollicis longus in the treatment of spastic thumb-in-palm deformity J Hand Surg 1985; 10: 553-60.

32. Rayan GM, Saccone PG. Treatment of spastic thumb-in-palm deformity: A modified extensor pollicis longus tendon rerouting. J Hand Surg 1996; 21: 834-9. [CrossRef]

33. Filler BC, Stark H, Boyes JH. Capsulodesis of the metacarpophalangeal joint of the thumb in children with cerebral palsy. J Bone Joint Surg 1976; 58: 667-70 